\title{
A Performance Evaluation Tool for Inclusiveness in University Campus Outdoor Spaces
}

\author{
Üniversite Yerleşkesi Dış Mekanlarının Kapsayıcılığı için \\ Performans Değerlendirme Aracı
}

\author{
ilkay DiNÇ UYAROĞLU
}

\section{ABSTRACT}

Education and right to access are among central issues of a democratic public life as well as higher education. Inclusion of students with disabilities (SWDs) in university campuses necessitates a holistic campus design beyond compliance, calling for a wide-ranging and systematic design with guiding inclusive design parameters. This is a significant prerequisite in Turkey since SWDs experience spatial exclusions in university campus spaces due to piecemeal and case-based design applications. Its achievement depends on co-experienced and thereby co-explored way of understanding collective voices of all users. This study is aiming at exploring design parameters for inclusive university campus outdoor spaces together with the shared spatial experiences addressing needs, desires, and preferences of SWDs in an equal way. To achieve it, firstly, a field study was conducted to comprehend spatial experiences of 'real' users in Middle East Technical University (METU); secondly, the field research is evaluated within the context of Kevin Lynch's (1981) normative theory to discover, analyze, and contextualize inclusive design parameters of outdoor campus spaces. Campus Accessibility Evaluation Index (CAEI) is created with the help of empirically grounded design parameters to test the developed normative framework within the study. This study claims that proposed performance evaluation tool can fill in a gap between technical and theoretical sources through the holistic guidance of inclusive architectural practices in university campuses for all.

Keywords: Accessibility index; equitable access; inclusive space; performance evaluation; university campus.

ÖZ

Eğitim ve erişim hakkı, yüksek öğrenimin yanı sıra demokratik bir kamusal yaşamın temel konuları arasındadır. Engelli öğrencilerin üniversite kampüslerinde eşit katılımı için, zorunluluğun ötesinde, kapsayıcı tasarım parametrelerine rehberlik eden geniş kapsamlı ve sistematik bir yaklaşımla bütüncül bir kampüs tasarımı gereklidir. Bu, Türkiye'de önemli ve gerekli bir önkoşuldur çünkü engelli üniversite öğrencileri, bireysel taleplerle gerçekleştirilen parçacı uygulamalar nedeniyle üniversite kampüs mekânlarında tam ve eşit katılım sağlayamamaktadırlar. Bunun başarısı, birlikte deneyimlenmeye ve dolayısıyla tüm kullanıcıların seslerini birlikte anlamaya bağlıdır. Bu çalışma, engelli öğrencilerin ihtiyaçlarını, isteklerini ve tercihlerini eşit ve katılımcı bir yolla ele alan ortak mekânsal deneyimlerle birlikte, kapsayıcı üniversite kampüsü dış mekanlarının tasarım parametrelerini keşfetmeyi amaçlamaktadır. Bu amaçla, 'gerçek' kullanıcıların mekânsal deneyimlerini anlamak için Orta Doğu Teknik Üniversitesi (ODTÜ) yerleşkesinde alan çalışması yürütülmüştür; ikinci olarak alan araştırması bulguları, Kevin Lynch'in (1981) normatif teorisi bağlamında değerlendirilerek, kapsayıcı kampüs dış mekân tasarım parametreleri için kavramsal çerçeve sunulmuştur. Keşfedilen ampirik temelli tasarım parametreleri yardımıyla geliştirilen normatif çerçeveyi test etmek için Kampüs Erişilebilirlik Değerlendirme Indeksi (KED) geliştirilmiştir. Üniversite kampüs yerleşkesi kapsayıcı dış mekân tasarımı için geliştirilen performans değerlendirme aracının, mekânsal uygulamaların eşit erişim fırsatlarına imkân verebilecek bütüncül bir yaklaşımla tasarlanmasına katkı koyacağı ve bu yolla teknik ve teorik kaynaklar arasındaki boşluğu doldurabileceği düşünülmektedir.

Anahtar sözcükler: Erişilebilirlik indeksi; eşit erişim; kapsayıcı mekân; performans değerlendirme; üniversite yerleşkesi.

This article was produced from the thesis study titled "Performance Evaluation and Design Guidelines for Equitable Access of Students with Disabilities in University Campus Outdoor Environments" prepared by Ilkay Dinç UYAROĞLU under the supervision of Professor Ali CENGIZKAN and Selahattin ÖNÜR at Middle East Technical University Department of Architecture Doctorate Program.

Department of Interior Architecture and Environmental Design, Ostim Technical University Faculty of Architecture and Design, Ankara, Turkey 


\section{Introduction}

Higher education leads to an increase in individuals' capabilities and their level of self-sufficiency, which in turn increases their quality of life (Barnes, 2007; UN, 2006). The level of accessibility for students with disabilities (SWDs) in university campus spaces depends on the fit between the needs of SWDs and proposed facilities, services, and activities in an institution (Lynch, 1981; Huger, 2011). Conceiving effectiveness of their spatial use in terms of equal access to all spaces should be addressed in the earliest phases of the design process. By this way, the ability to equally participate in spontaneous meetings or events and to make sudden changes in decisions about educational and social activities can be achieved (Marcus \& Wischemann, 1990). It is based on bilateral relationships between 'activities' (user needs) that a university offers and opportunities for 'participation' (design measures) in campus facilities and services (Imrie \& Hall, 2001; Clarkson et al., 2003). In this respect, accessibility has a catalytic role for SWDs' inclusion in campus life (Hay, 1995; Casas, 2007). Performance Evaluation (PE) concept builds on these interactive relationships between people and spaces (Preiser, 2002, p. 21). Constant performance evaluations of outdoor campus spaces are important in advancing equitable access of SWDs in campus life. Integration of the theme of accessibility into PE has been strongly emphasized, addressing the need to sustain the development of physical, social, and cultural inclusiveness in public life. This study argues that PE should not only search for physical accessibility issues but also respond to the social inclusion of SWDs in university spaces.

In Turkey, the rights to equitable access of SWDs in learning environments was enacted in 2005 by Disability Law no 5368. It facilitated the adoption of the 'Regulation on Collaboration and Coordination of Higher Education Institutions for Persons with Disabilities' (YÖK, 2006, 2010), addressing rules of how to best meet the requirements of SWDs to ensure their participation in universities in an equal manner. It states technical design specifications should be applied in all physical environments (YÖK, 2010). Although many efforts to provide accessible learning environments have been realized, SWDs still experience spatial exclusions in higher education institutions. It is mainly because of indifference towards unified normative approaches in policies and practices (Martins et al., 2017). Due to drawbacks in spatial design and applications, the Ministry of Family and Social Policies prepared the 'Regulation for Monitoring and Controlling Accessibility' (ASPB, 2013) to manage and force implementation of national technical design standards. It published the 'Forms for Monitoring and Controlling Accessibility' (Çiftçi \& Çağlayan Gümüş, 2017) which lists several current design standards and enhanced a checklist do describe whether a design is accessible or not. This complied way of controlling and implementation of design standards has caused piecemeal design applications in a lack of continuity, conformity, integration, and spatial insights of SWDs. Beyond worth emphasis, universities need to develop a unified and normative distinctive framework serving as a reliable mechanism for monitoring (re)design processes and implementations (Lissner, 2007; Gillies \& Dupuis, 2013).

Inclusive campus spaces are created by developing a holistic institutional approach involving all responsible stakeholders in or out of the institution (Lissner, 2007). Users have a core role in the creation of inclusive educational spaces, facilities, and services (Ostroff, 1997; Imrie \& Hall, 2001). This study uses the participatory process as a research tool for co-creation of the design parameters of university campus open spaces to promote independent and equal participation of SWDs in facilities, resources, and activities, arguing that this, in turn, will elicit their social inclusion. To accomplish the aim of the study, I conducted daily trips with 14 SWDs to understand their lived experiences in their educational environment, Middle East Technical University (METU), Ankara, Turkey. The sample included students with wheelchairs and severe visual impairments. Their spatial experiences are founded on extreme living circumstances so these two groups of users are selected as participants in this study. This can enhance comprehensive insights into how the spaces can respond to a wide range of user needs (Pullin, 2003). Considering equal rights of all students, this study aims to explore, scrutinize, and contextualize inclusive design parameters for campus outdoor spaces through the field study and lens of Lynch's (1981) performance dimensions for 'A Good City Form'. Campus Accessibility Evaluation Index (CAEI) is developed with the help of empirically grounded design parameters to test the established normative framework in the study.

\section{Participative Method: Users as Experts}

In evaluating spatial experiences, how spaces support (1) each type of activity; and (2) user experiences in both behavioral and social nature of spaces are important. User experiences are essential means to achieve the most reasonable and user-centered solution to design problems (Imrie, 2004, p. 279; Keates \& Clarkson, 2004, p. 220). Ostroff (1997) highlights that a user is regarded as an "expert" while confirming diversity of (dis)abilities in any types of physical settings. This expresses their strong roles in assessments of spaces.

The purpose of the field research is to identify spatial attributes affecting equitable access of SWDs, and consequently, equal participation in spaces. If the 
relationship between "activity" and "participation" is stronger within built environments as much as possible, spatial, and social inclusion of entire community members in public life can be achieved (Barnes, 2011; Gehl, 1987). Founded on this argument, a participatory research methodology that involves open-ended and semistructured interviews and participative observations (Sanders, 2002) was applied. The data was analysed by the content analysis method.

14 SWDs ( 5 of those with wheelchairs and 9 of those with severe visual impairments) participated in this study (Table 1). Given the low number of SWDs, graduated students were also asked to participate in the study. Data was collected by interviewing each participant in circulating the campus from August to November 2014. I followed each participants commonly used behavioral pattern in experiencing a one-day diary of activities in different times of the education term. It ranged from entering the campus to accessing to spaces or buildings. During the trips, I aimed at understanding the degree of access of the participants to outdoor spaces and buildings accommodating necessary, optional or social actions (Gehl, 1987). There was a further expectation to comprehend spatial variables whether they are favorable or discouraging for SWDs. The information gained from graduated students additionally included parts of their past and current spatial encounters, which is a valuable source to comprehend the impact of several spatial revisions to the inclusiveness of spaces.

\section{Lynch's Normative Approach}

Lynch (1981) addresses cities as sustaining culture and survival of the society as well as promoting the sense of association in time and space and allowing personal development in an equal manner. For him, a good city that is accessible, adaptable, and tolerant to experiment can respond to these circumstances (Lynch, 1981, pp. 166-117). Hence, 'efficiency' and 'justice' are the umbrella contexts of Lynch's normative theory by which he forms a universal framework to create a city life respecting equal rights of all users. Built upon them, Lynch (1981) proposes five performance dimensions, vitality, sense, access, fit, and control, to evaluate social and physical features of a good city. Based on his arguments, campus spaces should have competency and capacity to meet the spatial needs of students in an equal and balanced manner for the aim of enhancing inclusive learning opportunities. Viewing the design of a university's spatial environment for/with all, Lynch's normative theory can have a reliable and considerable conceptual relevance.

Among Lynch's (1981) five performance dimensions of a good city form, vitality, sense, access generally refers to matching the quality of spatial environments with users' spatial experiences. Adopted from these three parameters of Lynchian theory, in this study, safe access, sensing orientation, and equitable access are stated as guiding design criteria that tend to be applied for the design and/or occupancy analyses of spaces for/with the users (Table 2). The last two ones, 'fit' and 'control' maintain a systematic way of a design process. While the former generally brings equitable access into a discussion in dwelling on the relationship among time, space, and person, the latter mainly highlights the control of access to spaces both physically and socially. From this study's context, they can

Table 1. Participants

\begin{tabular}{|c|c|c|c|}
\hline USERS & ASSISTIVE TOOLS & ACCOMMODATION & EDUCATION \\
\hline \multicolumn{4}{|c|}{ with wheelchairs } \\
\hline UserA-1 & Manually-propelled wheelchair & With her family & 8-years \\
\hline UserA-2 & Electric-powered wheelchair & On campus & 5-years, graduated \\
\hline UserA-3 & Electric-powered wheelchair & On campus, with assistance & 3-years \\
\hline UserA-4 & Electric-powered wheelchair & With her family & 9-years, graduated \\
\hline UserA-5 & Manually-propelled wheelchair & With her family & 8-years \\
\hline \multicolumn{4}{|c|}{ with visual impairments } \\
\hline UserB-1 & Cane (95\% vision loss) & On campus & 3-years \\
\hline UserB-2 & None (85\% vision loss) & With her family & 5-years \\
\hline UserB-3 & Cane (blind) & On campus & 6-years \\
\hline UserB-4 & None (85\% vision loss) & On campus & 10-years, graduated \\
\hline UserB-5 & Cane (blind) & On campus & 5-years, graduated \\
\hline UserB-6 & Cane (90-95\% vision loss) & With her family & 5-years \\
\hline UserB-7 & None (60-90\% vision loss) & On campus & 7-years \\
\hline UserB-8 & Cane $(90-95 \%$ vision loss) & On campus & 4-years \\
\hline UserB-9 & Cane (95\% vision loss) & On campus & 2-months \\
\hline
\end{tabular}


Table 2. Evaluation of spatial sub-values of Lynch's performance dimensions

\begin{tabular}{|c|c|c|c|c|c|}
\hline \multirow{5}{*}{ 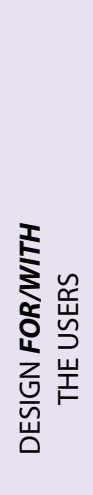 } & & \multicolumn{2}{|c|}{$\begin{array}{r}\text { A competence and capacity of } \\
\text { spaces to meet the needs of } \\
\text { people }\end{array}$} & \multicolumn{2}{|c|}{$\begin{array}{l}\text { Access to all public } \\
\text { opportunities in an equal } \\
\text { and balanced manner }\end{array}$} \\
\hline & & \multicolumn{2}{|r|}{ Efficiency } & \multicolumn{2}{|l|}{ Justice } \\
\hline & $\begin{array}{l}\text { Sustenance, } \\
\text { Safety, } \\
\text { Consonance }\end{array}$ & 1. Vitality & SAFE ACCESS & \multirow{3}{*}{ 4. Fit } & \multirow{3}{*}{ 5. Control } \\
\hline & $\begin{array}{l}\text { Identity of a } \\
\text { place, Legibility, } \\
\text { Orientation }\end{array}$ & 2. Sense & $\begin{array}{l}\text { SENSING } \\
\text { ORIENTATION }\end{array}$ & & \\
\hline & $\begin{array}{l}\text { Diversity, Equity } \\
\text { and Control of } \\
\text { access }\end{array}$ & 3. Access & $\begin{array}{l}\text { EQUITABLE } \\
\text { ACCESS }\end{array}$ & & \\
\hline & & & & \multicolumn{2}{|c|}{$\begin{array}{l}\text { DESIGN ON BEHALF } \\
\text { OF THE USERS }\end{array}$} \\
\hline
\end{tabular}

also be viewed as central subjects in the management and implementation of inclusive design measures, evaluating the environment on behalf of users. Based on this conceptual reading in the light of Lynch's normative theory, both the roles of designer and users are of equal importance in the whole design and occupancy process.

\section{Evaluation of Co-experienced Spatial Attributes in METU Campus Life}

The co-experienced data are expressed in addressing behavioral patterns of users- circulation, approach, and participation to outdoor campus spaces- in an equitable, safe access, sensing orientation, and equal participation in outdoor campus spaces.

\section{Circulation in Outdoor Campus Spaces}

The conditions of public vehicles serving in the city and campus are one of the fundamental barriers to circulation on campus. Since they are not accessible for users with electricpowered wheelchairs, they have to use manually operated wheelchairs by which they can access spaces with the help of someone. This limits their physical activities due to the need for someone and excessive physical power. Since it is impossible to use public transport facilities independently, three of five users with wheelchairs live in a dormitory on the campus although their families live in the same city. Among them, User A-3 has to utilize an accessible shuttle that is provided for SWDs since 2013 due to high-inclined sidewalks and walkways and some minor level changes along the route towards his department. However, as he implies, if equitable access was provided in the campus, he would prefer to independently access to spaces:

He [driver of the minibus] takes our course schedules. When I have a course, he takes me there and brings me back... However, it is not possible to make a spontaneous decision... If you ask, l'd rather take a bus or get on the subway if it [physical environment] was free of problems.

Without using any vehicles, User A-4 who moved to the vicinity of the campus can independently and easily access to outdoor campus spaces, which significantly increase her social relations:

...we moved to Çiğdem (nearly 20 minutes walking distance from the campus), which has given me more freedom... It is directly related to spatial conditions because I began to develop social relationships only after moving here.

All of the participants who are blind or with severe vision loss valued that shuttle stops have been in a certain place, which allows them to get on/out for a while. Since they may have wayfinding problems, they have to use them only in heavy weather conditions. All participants prefer to walk when accessing spaces/buildings instead of using the shuttle. Walking/wheeling is the best way to advance a true perception of the spatial environment by using different senses, such as touching, hearing, and smelling, which is crucial for independent and safe access to the freely chosen destination:

Here is a flat, very comfortable and nice Alley, so I do not use the shuttle... I have trouble figuring out where to get off. It is moving fast and is crowded, so you cannot see very well... Sometimes I may get off in the wrong place (User B-7).

All participants using canes had generally acquainted themselves with self-sufficient movement as soon as they started to live in the campus. This considerably encourages their easy, safe, and independent involvement in campus life thereby develops independent movement and personal self-reliance over time. They must access commonly used outdoor spaces since this allows them 
to effortlessly and quickly know and learn about the near locality, and in time, the whole outdoor campus spaces. The central point here is to enhance orientation cues in continuity, which advances the learning process of campus spaces, as implied by User B-3:

It terrifies me if it is somewhere I don't know... I prefer places that are familiar to me. I am open to new things, but I avoid going to distant places where I cannot get help when I have a problem.

\section{Approaching to Outdoor Spaces/ Buildings}

Spatial layout, design of the ground, and environmental elements perceived in different sensorial ways are the main themes contributing to participants' equitable and safe access and orientation to spaces/buildings. Firstly, spatial layout of 'Alley' which is the central pedestrian route connecting secondary access routes, building entrances, and outdoor spaces promotes independent access of the

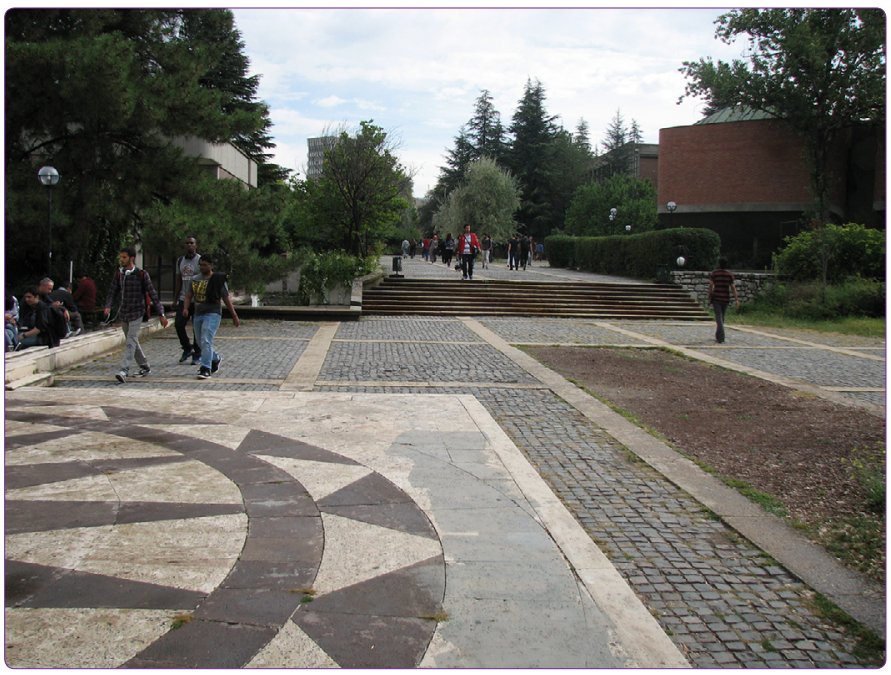

Figure 1. Entrance of the library.

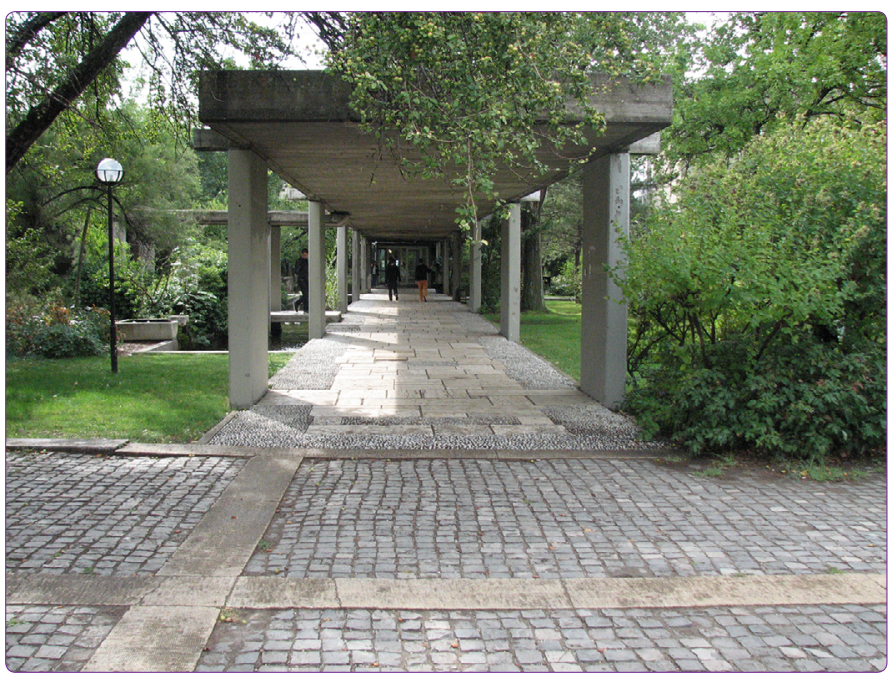

Figure 2. Portico of the Faculty of Architecture connected to Alley. participants (Figure 1, 2). Herein, it is essential to provide the shortest accessible route (Figure 3 ) to buildings through walking or wheeling from shuttle stops and parking areas to guarantee their timely arrival in lessons and examinations, particularly in snowy and frosty weathers (Figure 4). Secondly, due to handicaps about changes in levels and surface finishing through sidewalks, participants with wheelchairs need to discover another route to reach a destination or wait for help (Figure 5). For those with visual disabilities, various level changes, the location, and features of stairs and ramps, entrance platforms with different surface finishing contribute significantly to their orientation around the campus. Statements of User B-8 detail these concerns:

This place is very important for me. Such a platform is great for me. It tells me, 'you have come to the Library' or 'you are in the middle'.

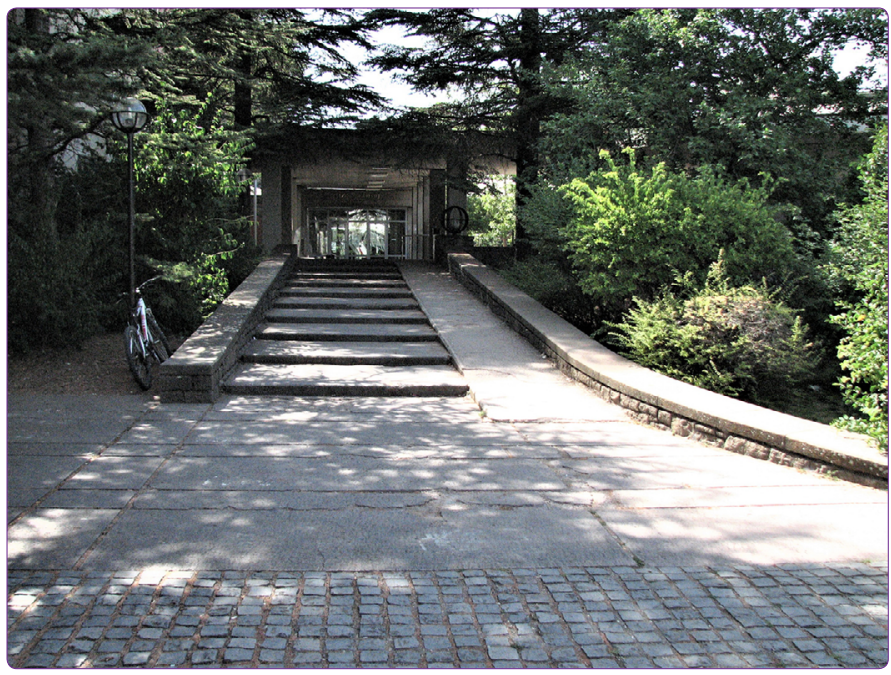

Figure 3. Inclusive access towards the Physics Building from Alley.

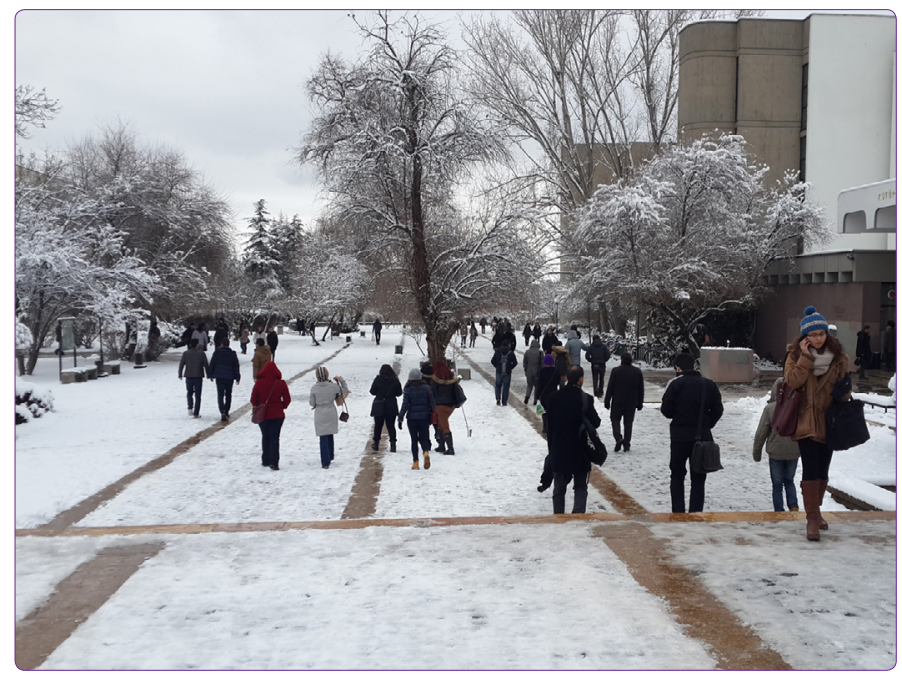

Figure 4. Alley in the winter. 


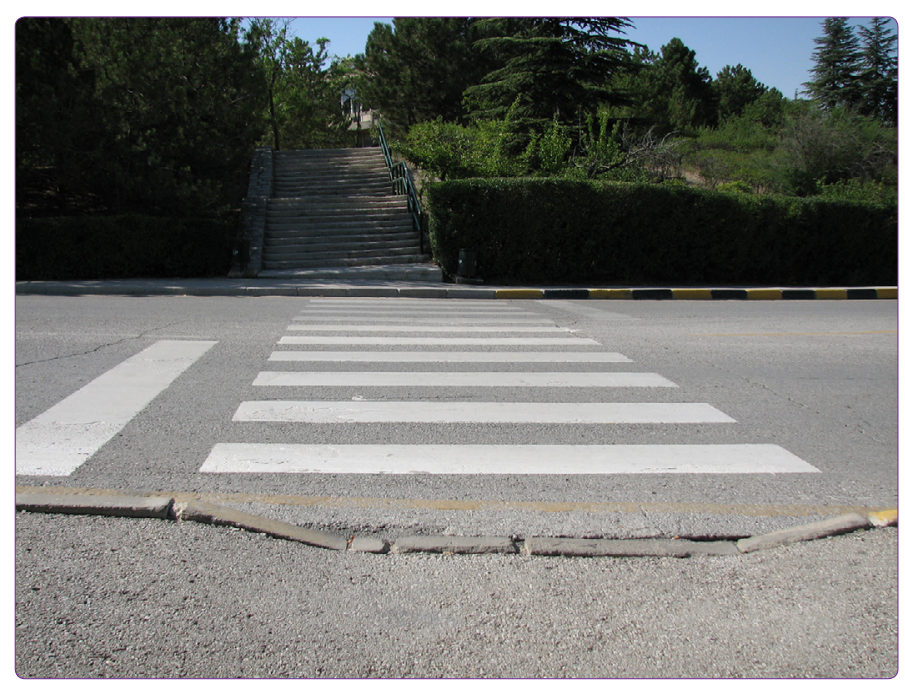

Figure 5. The most used crossing.

Design measures considering the needs of wheelchair users and those with visual impairments might overlap in some cases but might also conflict. For instance, perceptible ground surface materials may result in problems for all users if they are not technically suitable, becoming slippery in the rain. On the other part, ramps can be used by those with visual impairments to navigate the campus, while they are needed for physical access of wheelchair users.

Natural or built components could also guide participants with visual disabilities towards the spaces/buildings. Identifying an edge between surface coverings and sensing existing (non)-spatial environmental constituents (e.g., dustbins, lampposts, pools, and sounds) help them to find their way easily. Herein, the crucial issue is to decide their locations in enhancing clear accessible routes, as depicted by User B-5:

Following the line where the soil meets the sidewalk makes it easier for me to reach my destination... This dustbin was also there! (she is hitting) I know I need to go in turning slightly from here.

Due to current spatial barriers on the main routes, SWDs have to utilize longer routes, which causes losses of their time and effort. It significantly affects wheelchair users' ability to participate in planned or spontaneous happenings, and commonly limits the usability level of campus spaces. If a barrier exists on the route, presented access opportunities become practically meaningless. Experienced spatial handicaps have obvious effects on their behavioral uses of the campus, being largely separated from the most used circulation routes, as understood from the statements of User A-2:

'How do people go to the Library? It's just a short walk... but... I have to go there from the back road, where the parking lot is'.

\section{Equal Participation in Campus Life}

SWDs spend most of their time taking part in lessons and staying in classes, especially in their departments and involved in leisure activities inside or outside close to their department buildings. Joining a class in other departments results in loss of time and physical fatigue for them due to physical barriers in open areas. Efforts are made to eliminate the barriers through careful planning of lessons and examinations especially for students with wheelchairs. This case-based situation does not lead them to participate in diverse educational activities. Spontaneous and infrequent meetings in different department buildings may also force participants with visual impairments to use unidentified parts of the outdoor environment. They need help to participate in optional educational activities due to insufficient orientation cues. Although full success has not been achieved, all participants can begin to expand their behavioral patterns over time depending upon opportunities for participation in various necessary and optional activities. This considerably encourages the usage of unknown spaces, which promotes increasing personal self-confidence over time, as specified by User B-7:

I hesitated a lot in the past when someone invited me to a remote location that I didn't know... I am more courageous now... Being away from my family and living here alone has increased my self-confidence.

Engaging in social events with their colleagues is a challenge for the participants, due largely to inadequacies in the physical environment. Three participants with wheelchairs who have come across difficulties in accessing indoor or outdoor canteens of their department buildings addressed its implications towards founding a strong dialogue with their peers in the same department or faculty. User A-1 explains it as follows:

Our canteen is not accessible from either inside or outside. That's why I couldn't meet with my friends in the canteen during my undergraduate years. It is certainly something that affects my life as it makes it difficult for me to socialize, not just with my friends in the department, but with friends in other departments.

All participants are completely conscious of access chances in the vicinity of their department buildings. Deficiency of knowledge on physical access opportunities leads to a loss of motivation to go to remote locations. The first time they want to participate in academic, social, or leisure activities, they must first learn if they can access this place. This may require a considerable time and too much physical effort; therefore, the participants may hesitate to participate in such activities, as displayed by User A-3: 


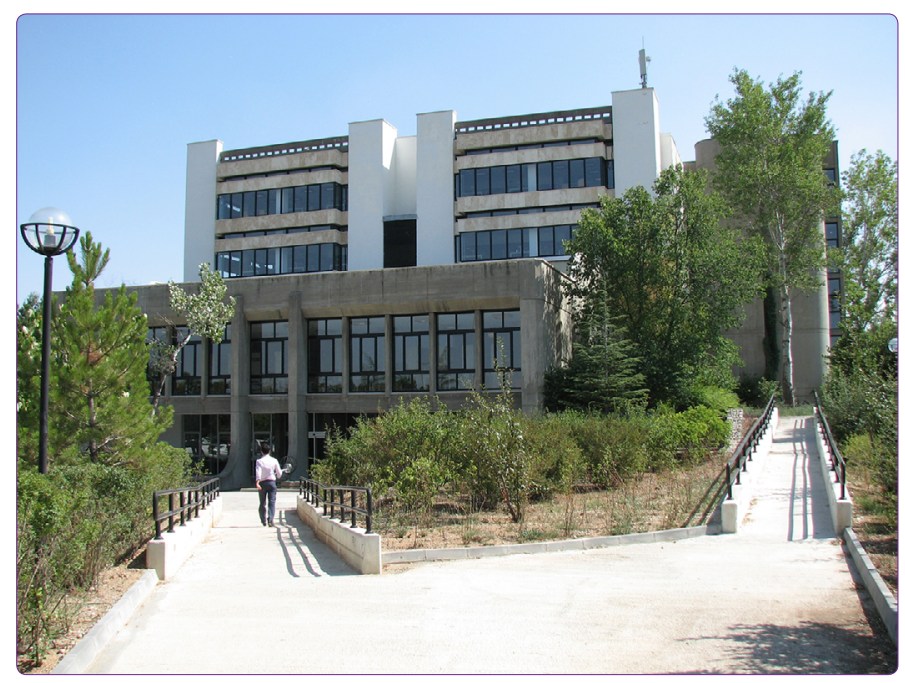

Figure 6. An accessible route integrated to Alley.

I have never gone to the cafeteria... It is troublesome for me to go there or enter the building. Can I enter there?... I have never gone to the pool, for example. I do not know how I could get there by myself... but swimming is the best sport for my muscles.

It is important for all participants that expansion of their behavioral patterns enhances the increase of personal courage to overcome challenges for participation in campus life. The more behavioral patterns match with commonly used patterns, the more satisfied the users are. If so, the participants can equitably access independently or collectively in using the shortest commonly used routes in-between spaces (Figure 6). The below statements of User A-1 display this matter:

You know! I am not able to go alone, somebody must be with me (due to physical environment) When we are a group of people, we suggest, 'Go ahead if you wish; we will go there by using that slope.' We offer an optional approach in this way. It is annoying.

\section{Discussions on Spatial Experiences: Performance Evaluation Design Parameters}

This study addresses that Equitable Access, Safe Access, and Sensing Orientation are the main performance dimensions in creating a university campus accessibility plan from an inclusive approach. Herein, Collective Control is the leading concept in the success of those three proposed parameters for the aim of managing the occupancy process and thereby steering the design process (Table 3 ). In the following, each dimension and its sub-contexts are discussed in its contextual basis; however, it is important to note that they are intertwined, interconnected, and dependent on one another through a chain of interrelation assumptions as shown in Table 3.

\section{Equitable Access}

Equitable access refers to campus spaces that permit equal and independent involvement of all campus members in all processes of access movement, circulation, approach, and participation. Physical diversity is very much connected to social diversity (Imrie \& Hall, 2001), in that the more people are in contact with spatial environment in an equal manner, the more they sense belonging to it (Lynch, 1981). Based on the results of the empirical research and conception of Lynch's normative philosophy, 'equitable access' can be described through the achievement of the following sub-dimensions in this study.

\section{Fitness of Behavioral Pattern}

Pairing a served accessible route with a commonly used route can increase an individual's number of opportunities for social inclusion (Lynch, 1981). As evidenced empirically in the fieldwork, pedestrian shortcuts between commonly used outdoor spaces and buildings can shorten travel times and efforts while increasing occasions for social interaction.

Table 3. Conceptual framework of performance evaluation and design guidelines

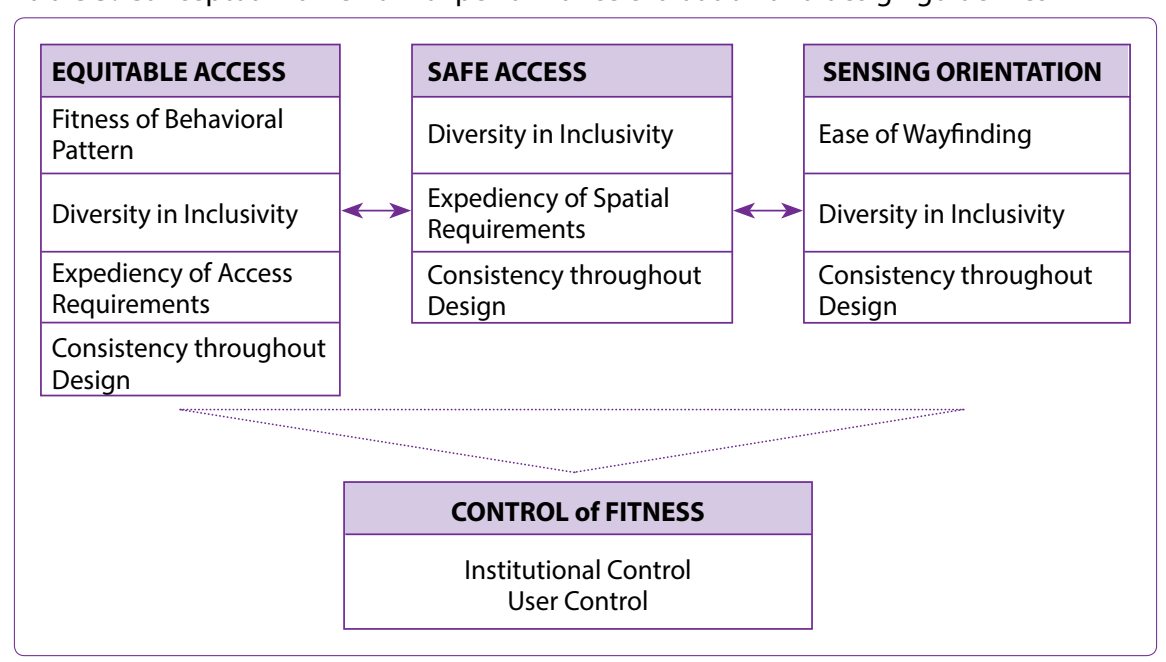


Designing walkways wide enough to accommodate wheelchair users alongside their friends supports collective use of spaces. Collective use appreciates both physical and social diversity, making each individual feel respected and belonged in learning environments (Gehl, 1987). Its constant control under unaccepted and time-varying circumstances is also essential to give SWDs a sense of security even in unforeseen events or disasters.

\section{Diversity in Inclusivity}

Diversity in inclusivity focuses on the spatial environment truly serving all people by enhancing various technical design requirements in an inclusive way (Imrie \& Hall, 2001). To accommodate various needs of SWDs, design solutions should be in harmony with the form of spatial setting (Lynch, 1981) and their overall behavioral pattern in the campus. Herein, the fundamental goal is to find a key solution through appropriate design solutions in a specific location. It is also necessary to serve various inclusive means of transport and to provide appropriate stop locations, to allow interconnected access in between spaces for SWDs' independent access regardless of day or weather changes.

\section{Expediency of Access Requirements}

Variety of design solutions in the best level of accordance is a substantial issue (Lynch, 1981). The effort to make every place accessible to everyone can cause complexity in built environments. Travel can be unsafe, disturbing, and difficult for SWDs as well as all community members. As evidenced by this study, the design accommodating requirements of all participants may overlap in some cases but may also conflict. Knowledge of overlapping and conflicting situations is important to reduce spatial complexity; this leads to the avoidance of contradictions and uncertain situations for all users.

\section{Consistency of Design}

Consistency of design exhibits a capacity of meeting diverse needs of users in a 'continuous' and 'coherent' way (Lynch, 1981). Suitable and guaranteed access requires application of design standards correctly and accurately in the right place along the common campus routes. The participants' experiences demonstrate that a cut-and-paste adoption of technical design standards could decrease self-confidence of SWDs to independently use outdoor spaces. Spaces should be well connected to paths of circulation in continuity to make campus spaces fully accessible to whole students while considering the delivery of new modes of access and repositioning of their origins and destinations.

\section{Safe Access}

Physical environments should be legible for all users (Lynch, 1981) to remove eventuality of hazardous facts and take required precautions, which means equitable access without anxiety (Story, 2001). Below sub-dimensions are for advancing the legibility of safety in outdoor campus spaces.

\section{Diversity in Inclusivity}

Different forms, colours, and textures of vertical and horizontal finishing along walkways deserve particular attention to inform potential risks, allowing people to easily recognize spatial forms and signs. In this respect, a variety of visual and auditory ways of information perceived by different senses should be presented as indicators of hazards (Lynch, 1981; Story, 2001). This would contribute to effective functioning of assistive devices (e.g. various types of wheelchairs and canes) in providing easy access to information.

\section{Expediency of Spatial Requirements}

There is always a risk of a hazard in spaces; however, the central substance in reducing accidental circumstances is the application of necessary design measures within a reasonable level (Lynch, 1981). Reconsidering behavioral patterns of a campus based on users' various access modes at any time may contribute to advancing tolerable levels of safe access and spatial use in a wide-ranging sense. In METU, since public transport stops are not generally placed in an appropriate place, relocation of them can contribute to further safety of users. (Re)design of spatial environment in enhancing tolerance to experiencing for all can encourage independent access of SWDs, even in unfamiliar spaces.

\section{Consistency of Design}

Continuous perceptibility and visual clearness of the spatial layout are essential to create a safe outdoor campus environment (Lynch, 1981). Experiential findings express that the boundaries in spaces where variations arise in level and texture on/through walkways can cause accidents for SWDs. Herein, illumination is vital to provide participants' access with feelings of safety at any time especially in rain or frost weather. These matters should dwell on a consistent and continuous way across the entire campus spaces.

\section{Sensing Orientation}

'Good orientation enhances access and good opportunity' (Lynch, 1981) clearly outlines the context of legibility in defining the level of perfect communication through representative and sensorial physical attributes. Legible spaces enhance easy and safe access for all (Lynch, 1981; Passini, 1984; Story, 2001). Below sub-parameters of sensing orientation widely shed light on regarding design principles.

\section{Ease of Wayfinding}

Ease of wayfinding is fundamental for a successful circulation system leading to equitable access and informing possible hazards in campus spaces (Lynch, 1981; 
Story, 2001). This is enhanced by perceiving existing spatial landmarks in-between spaces in continuity. Landmarks offering junctures for uninterrupted orientation in spaces (Passini, 1984) are categorized as the built and natural parts of the environment. For the participants using wheelchairs, ease of wayfinding becomes probable with legible accessible routes and a signage system inconsistency with general behavioral patterns. The issue has a parallel notion, but a particular emphasis should be noticed for those with visual impairments. Guide-paths are crucial for them; however, they generally constrain to use a linear axis. Evidence-based findings prove that spaces ought to direct SWDs at the most appropriate time and space, without confusing in crossing and changes in direction in the general pedestrian flow.

\section{Diversity in Inclusivity}

Spaces should include diverse spatial attributes to help navigate users through various senses (Story, 2001; Imrie \& Hall, 2001). Design attributes that satisfy participants' needs are based on the perception of circulation routes in various senses. As depicted by the cocreation process, the participants with visual impairments follow a series of spatial clues- vertical and horizontal boundaries, the formal characteristics of spatial parts (e.g., texture, slope, width), layout of walkways (e.g., straight, curved, and/ or angled) - to read the spatial layout for wayfinding. However, it is largely significant for users with wheelchairs in terms of safety rather than orientation. In general, 'static'- formal attributes of the ground-and 'permanent' environmental elements (e.g., sounds of pools and flows of people) are worked as reliable reference symbols for wayfinding. The role of wayfinding signage system is basically for advancing an independent and equitable way of wayfinding for SWDs. In this respect, all participants of the study especially those newcomers also need a campus accessibility map to use campus spaces easily and independently. The comprehensive and integrated offering of these various design solutions allows whole campus users to be entertained in terms of access, safety, and orientation.

\section{Consistency of Design}

Realizing spatial attributes in a consistent approach (Lynch, 1981) allows SWDs to navigate easily, independently, and comfortably in whole campus spaces (Passini, 1984). Participants with visual impairments engage with consistent, static, and reliable landmarks to be independently directed to targeted locations in an equal manner. A proper placing of diverse kinds of landmarks and uninterrupted connection between them should be protected through day/night-time in different weather conditions. This supports access without reluctance in developing cognitive recording of the whole spatial network of the campus, which certainly benefits users with partial or total visual loss. Applying creative (re)design measures to promote easy and equitable spatial orientation is significant and consistency between such measures needs to be constantly (Lissner, 2007) guaranteed throughout outdoor campus spaces.

\section{Control of Fitness}

'Control' dwells on the capability of the society for utilizing and adapting spaces and having rights to resolve how it is developed, which causes place attachment and further ownership on that place (Lynch, 1981). Based on this idea, control of fitness is a collective responsibility of the whole campus community on two main planes- user and institutional. Close partnerships between campus users and its administrative body having the authority to regulate and enforce policies are vital to certify constructive social revolution (Lissner, 2007). The notion of an impact-response collaboration among them emerges from the idea of 'democratic campus life' (Gillies \& Dupuis, 2013; Raheja \& Suryawanshi, 2014).

The power, ability, and self-determination of users to modify their campus spaces according to their experiences, evaluations, demands, and complaints should be considered to secure equitable access in their learning environment (Ostroff, 1997; Sanders, 2002). In the METU case, an activist power of students facilitates the realization of spatial, and consequently, social development for democratic campus life. This facilitates their active and collective participation in decision-making process at each stage of spatial (re)design. All campus users, in general, share a similar responsibility while observing the environment for their benefit. Participants of this research and their colleagues, whether officially or not, are cooperatively a part of the control process. This makes SWDs feel more valued, confident, included, and a sense of belonging in campus life. As verified in this case, even though practices for spatial access have been carried out quite slowly, openness and sensitivity of the university towards feedbacks of and for SWDs encourage their active involvement in the development of inclusive campus life.

Institutional control is about how inclusive design parameters can be cooperatively developed and achieved in both attitudes and applications by the whole university entity. For its success, the university should develop a comprehensive and holistic plan, beyond only obeying the codes particular to special groups of users, highlighting "how the spatial setting responds to the needs of its users in an equal way (Lissner, 2007). A (re)design team involving experts of design professionals and social scientists as well as all responsible parts of an institutional body should work with the whole body of users covering SWDs, to disclose at what level a spatial design proposal 
equally responds to intentions and perceptions of all users. The institutional sensitivity in responding to SWDs' spatial needs creates a culture of belonging. As evidenced by the participants' viewpoints, sustaining inclusiveness of campus spaces is important since a university is a longstanding foundation by which students continue to form and sustain social relationships, despite having graduated long ago.

\section{Implementation of Performance evaluation parameters: A proposal of Campus Accessibility Evaluation Index (CAEI)}

A Campus Accessibility Evaluation Index (CAEI) (Table 4 ) is the certification showing the degree of inclusiveness in outdoor campus spaces. It is structured on three performance dimensions which are Equitable Access, Safe Access, and Sensing Orientation. They include 48 subdimensions in total. Design criteria in different performance dimensions seem to overlap in some instances but in the assessments of the spaces, each sub-dimension as a distinct design criterion is appraised within the scope of regarding performance dimension. In the proposed CAEI, each design criterion having a qualitative and empirical basis in nature matches with quantitative essentials, that is, the mandatory design standards.

Based on a Weighted Arithmetic Mean method, the performance score of each design criterion is appraised on account of the weighted values rankings and user satisfaction levels. Weighted values, ' 1 (required)' and '2 (must)', demonstrate the significance level of design criteria for the users. The significance value of each design criterion is decided according to the empirically investigated data through the METU sample and technical design standards dictated by national legislations. CAEI involves a 4-point evaluation scale from ' 0 ' to ' 3 ' $(0$ : Not at all; 1: Somewhat; 2: Adequate; 3: Very good) for users' evaluations on spaces.

Having estimated the performance level of each design dimension, CAEI delivers a sum score for each of three performance dimensions, Equitable Access, Safe Access, and Sensing Orientation. The total amount of the scores of these performance dimensions give the result of the inclusivity degree of the spatial environment. Herein, the degree of the sum performance mean for inclusiveness in spaces is clustered into three groups: A- Inclusive, (70\%-100\%); B- Tolerable, (40\%-70\%); and C- Exclusive $(0 \%-40 \%)$. If the sum performance score is between 70 and 100 percent, the evaluated site is interpreted as inclusive, which means encouraging equitable access of SWDs. When it ranges from 40 to 70 percent, the built environment is stated as tolerable. The outcome score of between 0 and 40 percent indicates that SWDs are significantly deprived of access to spaces and participation in campus life activities, which causes exclusion of SWDs in campus public life.

\section{Application of CAEI}

CAEl was tested in a part of the METU campus field which is located at the center of campus public life. The selected field involves the library and many departmental buildings and amphitheater which is frequently used by all campus members for participating in academic, social, art, and cultural activities. The field also covers commonly used outdoor spaces in between buildings. The selected field was analyzed based on the findings on in-depth interviewing with the participants while traveling with them on the site. The empirical findings are depicted on two separate maps according to the types of disability that participants have (Figure 7, 8). According to them, the participants can travel throughout the site but the behavioral patterns of the students with wheelchairs

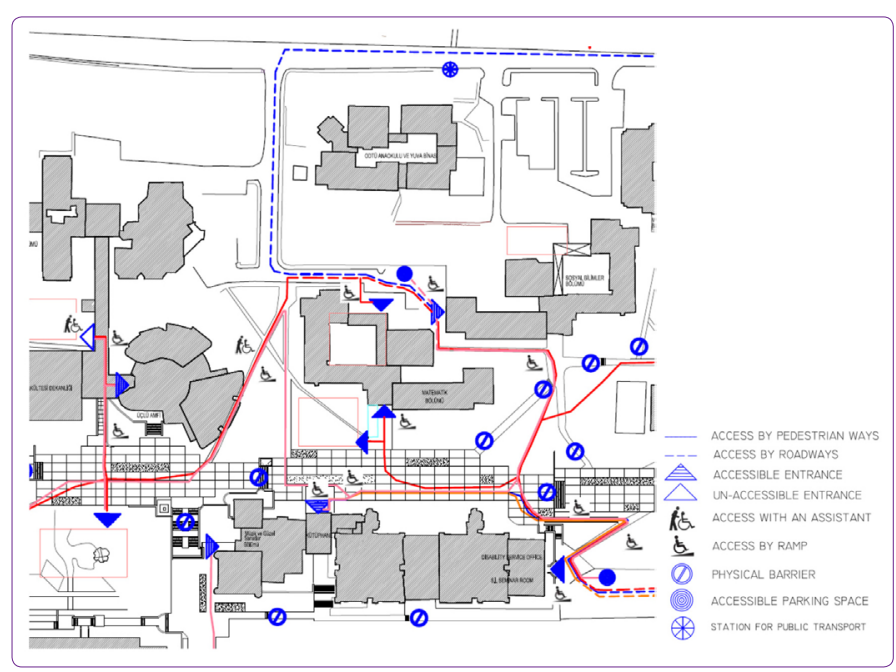

Figure 7. Appraisal of the site with the participants with wheelchairs.

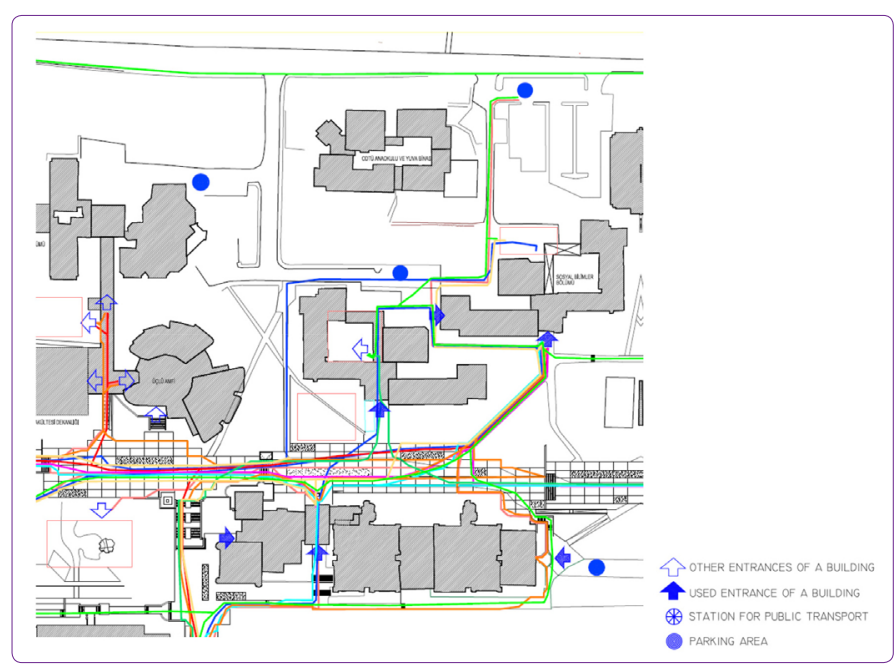

Figure 8. Appraisal of the site with the participants with visual impairments. 
Table 4. Evaluation results of the site using CAEI

\begin{tabular}{|c|c|c|c|c|c|c|c|}
\hline PERFORMANCE DIMENSIONS & $\begin{array}{l}\text { Weighted } \\
\text { Values }\end{array}$ & $\begin{array}{l}\text { Assessment } \\
\text { Method }\end{array}$ & \multicolumn{2}{|c|}{$\begin{array}{l}\text { Ranking Ranking } \\
\text { (User (User } \\
\text { group A) group B) }\end{array}$} & \multirow[t]{2}{*}{$\begin{array}{l}\text { Average } \\
\text { Ranking }\end{array}$} & \multicolumn{2}{|c|}{ Sum score } \\
\hline \multicolumn{7}{|l|}{ EQUITABLE ACCESS } & \\
\hline \multicolumn{8}{|l|}{ Fitness } \\
\hline $\begin{array}{l}\text { The level of fitness between commonly used } \\
\text { pedestrian routes and the spatial behavior of } \\
\text { SWDs }\end{array}$ & 2 & $\begin{array}{l}\text { SO } \\
\text { UA }\end{array}$ & 2 & 3 & 2.5 & $\begin{array}{c}5 \\
\left(2.5^{*} 2\right)\end{array}$ & 6 \\
\hline $\begin{array}{l}\text { Designing origins and arrivals of existing } \\
\text { access modes (by transportation vehicles) to } \\
\text { a certain reasonable level }\end{array}$ & 2 & SO;UA & 1 & 2 & 1.5 & $\begin{array}{c}3 \\
(1.5 * 2)\end{array}$ & 6 \\
\hline \multicolumn{8}{|l|}{ Diversity } \\
\hline $\begin{array}{l}\text { Incorporating diverse design measures in an } \\
\text { inclusive way in response to the extreme } \\
\text { needs of campus users }\end{array}$ & 2 & SO;UA & 1 & 2 & 1.5 & $\begin{array}{c}3 \\
(1.5 * 2)\end{array}$ & 6 \\
\hline $\begin{array}{l}\text { Suggesting design solutions peculiar to a } \\
\text { space through an interpretation of design } \\
\text { standards rather than using them in a copy- } \\
\text { paste approach }\end{array}$ & 2 & SO & 2 & 2 & 2 & $\begin{array}{c}4 \\
(2 * 2)\end{array}$ & 6 \\
\hline $\begin{array}{l}\text { Enhancing collective usage of commonly } \\
\text { used campus outdoor spaces through a } \\
\text { general circulation route }\end{array}$ & 2 & SO;UA & 1 & 2 & 1.5 & $\begin{array}{c}3 \\
(1.5 * 2)\end{array}$ & 6 \\
\hline $\begin{array}{l}\text { Designing all natural and manmade } \\
\text { environmental components (i.e., bins, } \\
\text { lampposts, trees) in an appropriate form and } \\
\text { position }\end{array}$ & 2 & SO;UA & 3 & 2 & 2.5 & $\begin{array}{c}5 \\
(2.5 * 2)\end{array}$ & 6 \\
\hline $\begin{array}{l}\text { Presenting optimum modal mix among and } \\
\text { between various access modes (i.e., railway, } \\
\text { bus, dolmuş, as well as pedestrian access) in } \\
\text { the general circulation network }\end{array}$ & 2 & SO & 1 & 2 & 1.5 & $\begin{array}{c}3 \\
(1.5 * 2)\end{array}$ & 6 \\
\hline $\begin{array}{l}\text { Providing accessible transportation options } \\
\text { and convenient transit stop locations in an } \\
\text { interconnected way, if needed, with the } \\
\text { delivery of new access modes and the } \\
\text { relocation of origins }\end{array}$ & 2 & $\mathrm{SO}$ & 1 & 2 & 1.5 & $\begin{array}{c}3 \\
\left(1.5^{*} 2\right)\end{array}$ & 6 \\
\hline $\begin{array}{l}\text { Providing independent access at night to } \\
\text { commonly used outdoor spaces in which } \\
\text { students may engage in academic, leisure, } \\
\text { cultural, recreational, sport and health- } \\
\text { related activities }\end{array}$ & 2 & SO;UA & 0 & 1 & 0.5 & $\begin{array}{c}1 \\
(0.5 * 2)\end{array}$ & 6 \\
\hline $\begin{array}{l}\text { Managing accessibility measures considering } \\
\text { seasonal factors such as rain and snow }\end{array}$ & 2 & SO & 0 & 1 & 0.5 & $\begin{array}{c}1 \\
(0.5 * 2) \\
\end{array}$ & 6 \\
\hline \multicolumn{8}{|l|}{ Expediency } \\
\hline $\begin{array}{l}\text { Distribution of access among students in an } \\
\text { equal manner to allow them to benefit from } \\
\text { all post-secondary services in the most } \\
\text { modest way possible }\end{array}$ & 2 & SO;UA & 1 & 2 & 1.5 & $\begin{array}{c}3 \\
(2 * 1.5)\end{array}$ & 6 \\
\hline $\begin{array}{l}\text { Reducing spatial complexity in design for the } \\
\text { avoidance of contradictions, and ambiguous } \\
\text { and uncertain circumstances }\end{array}$ & 2 & SO & 2 & 1 & 1.5 & $\begin{array}{c}3 \\
\left(1.5^{*} 2\right)\end{array}$ & 6 \\
\hline $\begin{array}{l}\text { Ensuring a reasonable level of physical effort } \\
\text { and distance }\end{array}$ & 1 & SO;UA & 2 & 3 & 2.5 & $\begin{array}{c}2.5 \\
\left(2.5^{*} 1\right) \\
\end{array}$ & 3 \\
\hline \multicolumn{8}{|l|}{ Consistency } \\
\hline $\begin{array}{l}\text { Ensuring consistency of the design } \\
\text { approach in all accessibility applications }\end{array}$ & 2 & SO & 1 & 1 & 1 & $2\left(2^{*} 1\right)$ & 6 \\
\hline $\begin{array}{l}\text { Ensuring continuity of access to guarantee } \\
\text { independent and equal means of access to } \\
\text { spaces, services, and facilities }\end{array}$ & 2 & SO;UA & 2 & 2 & 2 & $4(2 * 2)$ & 6 \\
\hline
\end{tabular}


Table 4. Evaluation results of the site using CAEI (continue)

\begin{tabular}{|c|c|c|c|c|c|c|c|}
\hline $\begin{array}{l}\text { Realization of a hierarchical system of spatial } \\
\text { behavior in an equal manner - approaching, } \\
\text { entering, and using - in each commonly } \\
\text { used outdoor space }\end{array}$ & 2 & SO;UA & 1 & 2 & 1.5 & $\begin{array}{c}3 \\
(1.5 * 2)\end{array}$ & 6 \\
\hline $\begin{array}{l}\text { Elimination of all environmental barriers } \\
\text { along the boundary of walking routes that } \\
\text { break continuity, either on the sidewalk or on } \\
\text { other pedestrian ways }\end{array}$ & 2 & SO & 2 & 1 & 1.5 & $\begin{array}{c}3 \\
(1.5 * 2)\end{array}$ & 6 \\
\hline $\begin{array}{l}\text { Ensuring continuity between access modes } \\
\text { in a way that provides equal usage }\end{array}$ & 2 & SO & 1 & 2 & 1.5 & $\begin{array}{c}3 \\
(1.5 * 2) \\
\end{array}$ & 6 \\
\hline $\begin{array}{l}\text { Making less-used pedestrian circulation } \\
\text { routes more tolerant to experimentation in } \\
\text { use }\end{array}$ & 1 & SO & 0 & 1 & 0.5 & $\begin{array}{c}0.5 \\
\left(0.5^{*} 1\right)\end{array}$ & 3 \\
\hline Cumulative score & 35 & & & & & 55 & 108 \\
\hline $\begin{array}{l}\text { Total cumulative score of } \\
\text { EQUITABLE ACCESS (Out of 100) }\end{array}$ & & & & & $55 / 108$ & $50,93 \%$ & \\
\hline \multicolumn{8}{|l|}{ SAFE ACCESS } \\
\hline \multicolumn{8}{|l|}{ Diversity } \\
\hline $\begin{array}{l}\text { Addressing unevenness, slippery surfaces, } \\
\text { and instability of all ground levels }\end{array}$ & 2 & SO;UA & 2 & 2 & 2 & $4(2 * 2)$ & 6 \\
\hline $\begin{array}{l}\text { Eliminating vertical and horizontal } \\
\text { protruding elements and other potential trip } \\
\text { hazards within the boundary of the } \\
\text { pedestrian way }\end{array}$ & 2 & SO & 2 & 2 & 2 & $4(2 * 2)$ & 6 \\
\hline $\begin{array}{l}\text { Informing about level differences through } \\
\text { different forms and colors of ground surface } \\
\text { finishing }\end{array}$ & 2 & SO & 3 & 2 & 2.5 & $\begin{array}{c}5 \\
(2.5 * 2)\end{array}$ & 6 \\
\hline $\begin{array}{l}\text { Providing information via visual and auditory } \\
\text { means, to be perceived by different senses } \\
\text { warnings where necessary }\end{array}$ & 2 & SO;UA & 1 & 1 & 1 & $2(2 * 1)$ & 6 \\
\hline $\begin{array}{l}\text { Ensuring sufficient lighting and appropriate } \\
\text { material choices for the built environment to } \\
\text { make spaces clearly legible at night }\end{array}$ & 2 & SO;UA & 1 & 0 & 0.5 & $\begin{array}{c}1 \\
\left(0.5^{*} 2\right)\end{array}$ & 6 \\
\hline $\begin{array}{l}\text { Providing continuity of access under } \\
\text { different weather conditions through } \\
\text { existing surveillance measures }\end{array}$ & 2 & SO & 0 & 1 & 0.5 & $\begin{array}{c}1 \\
(0.5 * 2)\end{array}$ & 6 \\
\hline $\begin{array}{l}\text { Ensuring easy evacuation to guarantee the } \\
\text { well-being of all users in the event of } \\
\text { unforeseeable disasters } \\
\text { Expediency }\end{array}$ & 2 & SO & 1 & 2 & 1.5 & $\begin{array}{c}3 \\
(1.5 * 2)\end{array}$ & 6 \\
\hline $\begin{array}{l}\text { Providing a balance between design } \\
\text { applications for physical access and safety to } \\
\text { always minimize hazards to a reasonable } \\
\text { level, and under any conditions }\end{array}$ & 2 & SO;UA & 2 & 3 & 2.5 & $\begin{array}{c}5 \\
\left(2.5^{*} 2\right)\end{array}$ & 6 \\
\hline $\begin{array}{l}\text { Planning transportation facilities (i.e., } \\
\text { relocation of bus stops) based on current } \\
\text { access modes of the users to increase the } \\
\text { level of safety }\end{array}$ & 2 & SO;UA & 3 & 3 & 3 & $6(3 * 2)$ & 6 \\
\hline \multicolumn{8}{|l|}{ Consistency } \\
\hline $\begin{array}{l}\text { Uninterrupted perceptibility and visual } \\
\text { clarity of the route layout, regardless of time } \\
\text { of day or weather conditions }\end{array}$ & 2 & SO;UA & 3 & 2 & 2.5 & $\begin{array}{c}5 \\
\left(2.5^{*} 2\right)\end{array}$ & 6 \\
\hline $\begin{array}{l}\text { Guaranteeing formal qualities of the route } \\
\text { layout - slope, surface, width, and pathway } \\
\text { edge }\end{array}$ & 2 & SO;UA & 2 & 3 & 2.5 & $\begin{array}{c}5 \\
(2.5 * 2)\end{array}$ & 6 \\
\hline $\begin{array}{l}\text { Taking essential measures at points where } \\
\text { there are changes in position of spatial } \\
\text { components, and vertical and horizontal } \\
\text { surface finishes throughout the campus }\end{array}$ & 2 & SO & 2 & 1 & 1.5 & $\begin{array}{c}3 \\
\left(1.5^{*} 2\right)\end{array}$ & 6 \\
\hline $\begin{array}{l}\text { Ensuring a continuously well-lit spatial } \\
\text { environment }\end{array}$ & 2 & SO & 2 & 1 & 1.5 & $\begin{array}{c}3 \\
(1.5 * 2) \\
\end{array}$ & 6 \\
\hline Ensuring users gain a feeling of safety & 1 & SO;UA & 2 & 3 & 2.5 & $\begin{array}{c}5 \\
\left(2.5^{*} 2\right)\end{array}$ & 6 \\
\hline
\end{tabular}


Table 4. Evaluation results of the site using CAEI (continue)

\begin{tabular}{|c|c|c|c|c|c|c|c|}
\hline Cumulative score & & & & & & 52 & 81 \\
\hline $\begin{array}{l}\text { Total cumulative score of } \\
\text { SAFE ACCESS }\end{array}$ & & & & & $52 / 81$ & $64.20 \%$ & \\
\hline \multicolumn{8}{|l|}{ SENSING ORIENTATION } \\
\hline \multicolumn{8}{|l|}{ Ease of Wayfinding } \\
\hline $\begin{array}{l}\text { Making circulation route layout easily } \\
\text { understandable }\end{array}$ & 1 & SO;UA & 2 & 1 & 1.5 & $\begin{array}{c}3 \\
(1.5 * 2) \\
\end{array}$ & 3 \\
\hline $\begin{array}{l}\text { Enhancing visual and sensorial perception of } \\
\text { existing spatial landmarks in continuity }\end{array}$ & 2 & SO;UA & 3 & 3 & 3 & $6(3 * 3)$ & 6 \\
\hline $\begin{array}{l}\text { Directing users to the right place in a timely } \\
\text { manner, without confusion or complexity, } \\
\text { especially at crossing points and changes of } \\
\text { direction }\end{array}$ & 2 & SO;UA & 1 & 1 & 1 & $2(2 * 1)$ & 6 \\
\hline Providing a perceptible signage system & 2 & SO & 1 & 0 & 0.5 & $\begin{array}{c}1 \\
(0.5 * 2) \\
\end{array}$ & 6 \\
\hline $\begin{array}{l}\text { Integrating measures relating to natural } \\
\text { environmental elements such as trees, } \\
\text { flowers and water into the design as useful } \\
\text { landmarks for uninterrupted orientation }\end{array}$ & 1 & SO;UA & 3 & 3 & 3 & 3 & 3 \\
\hline \multicolumn{8}{|l|}{ Diversity } \\
\hline $\begin{array}{l}\text { Providing a variety of wayfinding } \\
\text { information, perceptible by the multiple } \\
\text { senses of individuals - sight, hearing, touch, } \\
\text { and smell }\end{array}$ & 2 & SO;UA & 3 & 3 & 3 & $6(3 * 2)$ & 6 \\
\hline $\begin{array}{l}\text { Providing static and permanent wayfinding } \\
\text { design attributes for reliable reference in } \\
\text { wayfinding }\end{array}$ & 2 & SO & 3 & 2 & 2.5 & $\begin{array}{c}5 \\
\left(2.5^{*} 2\right)\end{array}$ & 6 \\
\hline $\begin{array}{l}\text { Providing plain, smooth, non-slip and non- } \\
\text { reflective ground surface }\end{array}$ & 2 & SO;UA & 2 & 2 & 2 & $2(2 * 1)$ & 6 \\
\hline $\begin{array}{l}\text { Achieving a fit between spatial design } \\
\text { attributes and a perceptible and appropriate } \\
\text { signage system that includes a combination } \\
\text { of written, visual, and verbal information }\end{array}$ & 1 & SO;UA & 2 & 2 & 2 & $2(2 * 1)$ & 3 \\
\hline $\begin{array}{l}\text { Presenting the potential use of the } \\
\text { environment through a campus accessibility } \\
\text { map for easy and timely access for all }\end{array}$ & 1 & SO & 0 & 0 & 0 & $0(0 * 1)$ & 3 \\
\hline $\begin{array}{l}\text { Ensuring adequate lighting throughout the } \\
\text { general circulation pattern }\end{array}$ & 2 & SO;UA & 1 & 1 & 1 & $2(1 * 2)$ & 6 \\
\hline $\begin{array}{l}\text { Taking surveillance measures when weather } \\
\text { conditions change }\end{array}$ & 2 & SO & 1 & 1 & 1 & $2(1 * 2)$ & 6 \\
\hline \multicolumn{8}{|l|}{ Consistency } \\
\hline $\begin{array}{l}\text { Ensuring appropriate positioning and } \\
\text { location of various types of landmarks in a } \\
\text { consistent way }\end{array}$ & 2 & SO;UA & 2 & 2 & 2 & $2(2 * 1)$ & 6 \\
\hline $\begin{array}{l}\text { Designing form of the ground as the central } \\
\text { marker in wayfinding, beyond only working } \\
\text { on linear guidance through a perceptible } \\
\text { guidepath for users with visual impairment }\end{array}$ & 2 & SO & - & 3 & 3 & $6(3 * 2)$ & 6 \\
\hline $\begin{array}{l}\text { Ensuring standardization of orientation } \\
\text { design measures throughout all parts of the } \\
\text { environment }\end{array}$ & 2 & SO & 1 & 1 & 1 & $2(1 * 2)$ & 6 \\
\hline Cumulative score & & & & & & 44 & 78 \\
\hline $\begin{array}{l}\text { Total cumulative score of } \\
\text { SENSING ORIENTATION }\end{array}$ & & & & & $44 / 78$ & $56.41 \%$ & \\
\hline Average accessibility degree (out of 100) & & & & & & $56.55 \%$ & \\
\hline
\end{tabular}

and visual impairments are differed due to the spatial handicaps, especially in commonly used circulation routes and spaces in between buildings. This displays that all participants can access somehow in a tolerable degree; however, their experiences are not yet equitable.
The generated data from the empirical field research is introduced in the CAEI. Herein, as shown in Table 4, the evaluations of spaces by and for each group of the participants are inserted separately. The sum score of each performance dimension is calculated with the help of its 
weighted values which were gathered from the participants' viewpoints and observations and their valuations on that dimension. Table 4 indicates in detail that the degree of the analyzed physical environment is 50.93 percent in the manner of Equitable Access; 64.20 percent in terms of Safe Access; and 56.41 percent in terms of Sensing Orientation. The sum score of the accessibility level is 56.55 percent, which keeps within the ranking of B-Tolerable (40\%-70\%). The findings of the empirical research mentioned above and depicted in Figure 7 and Figure 8 match with the result of CAEI.

\section{Conclusion}

This study argues that co-evaluation of campus spaces with its 'real' users offers the reliable base for inclusively designed outdoor campus spaces in universities. Architects should develop new materials and spatial solutions in considering whole experiences in spaces, rather than depending merely on ready-made products and technical design specifications. This would be an underlying means to construct the design process of inclusive spaces while creating strong co-operation between the institution and users. To this end, this study explores empirically constructed normative design principles towards the implementation of the performance evaluation and design tool, CAEI, that is manageable in practice. It has a potential way of creating unlimited learning opportunities for all being integral with engaging ever-changing experiences, perceptions, and activities, which, then, can create democratic (in)formal learning environments (Carr \& Lynch, 1968). In this focus, the contribution of this study to the literature is twofold: (1) it offers an emergent contextual outline by scrutinizing the architecture and planning normative theory in a comprehensive interpretation at a local sample; (2) argues that the effort of this study to fill in the gap between theoretical design parameters and architectural practice contribute to the development of inclusiveness in built environments.

\section{References}

ASPB (Aile ve Sosyal Politikalar Bakanlı̆̆ı) (2013). Erişilebilirlik İzleme ve Denetleme Yönetmeliği [Regulation for Monitoring and Controlling Accessibility]. Resmi Gazete, 28713.

Barnes, C. (2007). Disability, Higher Education and Inclusive Society. British Journal of Sociology of Education, 28(1), 135-145. doi: 10.1080/01425690600996832

Barnes, C. (2011). Understanding Disability and the Importance of Design for All. Journal of Accessibility and Design for All, 1(1), 55-80. doi:10.17411/jacces.v1i1.81

Carr, S., \& Lynch, K. (1968). Where Learning Happens. Daedalus, 97(4), 1267-1281. https://www.jstor.org/stable/20013323

Casas, I. (2007). Social Exclusion and the Disabled: An Accessibility Approach. The Professional Geographer, 59(4), 463-477. doi: 10.1111/j.1467-9272.2007.00635.x.
Clarkson, P., Coleman, R., Keates, S., \& Lebbon, C. (Eds.). (2003). Inclusive Design: Design for the Whole Population. London, UK: Springer-Verlag.

Çiftçi, İ., \& Çağlayan Gümüş, D. (Eds.). (2017). Erişilebilirlik İzleme ve Denetleme Formları [Forms for Monitoring and Controlling Accessibility]. Ankara: Aile ve Sosyal Politikalar Bakanlığı 01.

Gehl, J. (1987). Life between buildings: using public space. (J. Koch, Trans.) New York: Van Nostrand Reinhold.

Gillies, J., \& Dupuis, S. L. (2013). A Framework for Creating a Campus Culture of Inclusion: A Participatory Action Research Approach. Annals of Leisure Research, 16 (3), 193-211. doi: 10.1080/11745398.2013.832646.

Hay, A. M. (1995). Concepts of Equity, Fairness and Justice in Geographical Studies. Transactions of the Institute of British Geographers, 20(4), 500-508. https://www.jstor.org/stable/622979.

Huger, M. S. (2011). Fostering a Disability-Friendly Institutional Climate. New Directions for Student Services, 134, 3-11. doi: 10.1002/ss.390.

Imrie, R., \& Hall., P. (2001). Inclusive Design: Designing and Developing Accessible Environments. London: Spon.

Imrie, R. (2004). From Universal to Inclusive Design in the Built Environment. In J. Swain, S. French, C. Barnes, \& C. Thomas (Eds.), Disabling Barriers- Disabling Environments (pp. 279284). London: Sage Publications.

Keates, S., \& Clarkson, J. (2004). Countering design exclusion and introduction to inclusive design. Great Britain: Springer.

Lissner, L. S. (2007). Universal Design in the Institutional Setting: Weaving a Philosophy into Campus Planning. In J. Nasar, \& J. Evans-Cowley (Eds.), Universal Design and Visitability: From Accessibility to Zoning (pp. 159-169). Ohio: John Glenn School of Public Affairs.

Lynch, K. (1981). A Theory of Good City Form. Cambridge MA: MIT Press.

Martins, M. H., Borges, M. L., \& Gonçalves, T. (2018). Attitudes Towards Inclusion in Higher Education in a Portuguese University. International Journal of Inclusive Education, 22(5), 527-542. doi:10.1080/13603116.2017.1377299.

Marcus, C., \& Wischemann, T. (1998). Campus outdoor spaces. In C. Marcus, \& C. Francis (Eds.), People places: design guidelines for urban open space, edited by, 175206. Canada: John Wiley \& Sons.

Ostroff, E. (1997). Mining Our Natural Resources: The User as Expert. Innovation, 16(1), 33. http://www.icsid.org/feature/ current/articles427.htm.

Passini, R. (1984). Wayfinding in Architecture. New York: Van Nostrand Reinhold.

Preiser, W. F. (2002). The Evolution of Post-Occupancy Evaluation: Toward Building Performance and Universal Design Evaluation. In Learning from Our Buildings: A State-of-thePractice Summary of Post-Occupancy Evaluation (pp. 9-22). Federal Facilities Council Technical Report No. 145. Washington, D.C.: National Academy Press.

Preiser, W. F., \& Vischer, J. C. (2005). The evolution of building performance evaluation: an introduction. In W. Preiser, \& J. Vischer (Eds.), Assessing Building Performance (pp. 3-14). Oxford: Elsevier.

Pullin, G. (2003). Inclusion, Inspiration and Lightness of Touch. In P.J. Clarkson, R. Coleman, S. Keates, \& C. Lebbon (Eds.), Inclu- 
sive Design: Design for the Whole Population (pp. 558-564). London: Springer-Verlag.

Raheja, G., \& Suryawanshi, S. (2014). Inclusive Strategies for Universal Access in Educational Campus Environments. In P. Langdon, J. Lazar, A. Heylighen, \& H. Dong (Eds.), Inclusive Designing Joining Usability, Accessibility, and Inclusion (pp. 93-104). Switzerland: Springer.

Sanders, E. B. (2002). From User-Centered to Participatory Design Approaches. In J. Frascara, Design and the Social Sciences: Making Connections (pp. 1-7). London: Taylor and Francis.

Story, M.F. (2001). Principles of Universal Design. In W.F.E. Preiser, \& E. Ostroff (Eds.), Universal Design Handbook (pp. 10.3
- 10.19). New York: McGraw-Hill.

UN (United Nations) (2006). Convention on the Rights of Persons with Disabilities and Optional Protocol. Retrieved on January 2, 2021 from https://www.un.org/disabilities/documents/ convention/convoptprot-e.pdf

YÖK (Yüksek Öğretim Kurumu) (2006). Yükseköğretim Kurumları Özürlüler Danışma ve Koordinasyon Yönetmeliği [Regulation on Collaboration and Coordination of Higher Education Institutions for Persons with Disabilities]. Resmi Gazete 26204.

YÖK (Yüksek Öğretim Kurumu) (2010). Yükseköğretim Kurumları Özürlüler Danışma ve Koordinasyon Yönetmeliği [Regulation on Collaboration and Coordination of Higher Education Institutions for Persons with Disabilities]. Resmi Gazete 27672. 